\title{
The Role of Banks in Reducing the Phenomenon of Money Laundering
}

\author{
Khalil Ibrahim Alsaif, PhD \\ Professor \\ Department of Computer \\ University of Mosul
}

\author{
Ramadan Mahmood Ramo \\ Management Information Systems \\ University of Mosul
}

\begin{abstract}
The phenomenon of money laundering is one of the forms of organized economic crimes aimed at legitimizing funds that are originally of illicit origin. As the world becomes a global village, as a result of the integration of the international financial markets, the policy of free economy and the freedom of trade, as well as the revolution of communications and the Internet. With the technological development in the banking and financial systems, the problem of money laundering is no longer self, Universal approach to human beings wherever they may be (Economic, financial, social and cultural).

Where money laundering is a form of transnational crime with a negative impact In terms of the size, structure and distribution of national income, Savings rates, unemployment, investment, rates, structure, climate and resource allocation Reflected negative effects on the stock market, the banking system.

Banks are one of the most important episodes in which illicit funds are organized in view of what they enjoy Of the complexity, speed and overlap of banking operations as money launderers cannot do so Operations without the use of services provided by the banking system, and it becomes increasingly complicated with progress Banking operations and the use of modern electronic services, which are easy to use In violation of the law, especially since most of these operations are carried out automatically and the possibility of control is needed To voltage, time and costs .
\end{abstract}

On the other hand, the banks themselves are the spearhead in combating money laundering activities In order to protect themselves from financial risks and the risk of losing customer confidence and collapse, and from accountability.

\section{Keywords}

Money Laundering, Banks, prevention measures, Detection Money Laundering.

\section{INTRODUCTION}

Money Laundering is concealing the transformation of profits from illegal activities and corruption into ostensibly "legitimate" assets.. It has been associated mainly with the drug trade and to a lesser crimes of bribery, tax evasion and political activities, Transfer of funds and using it by terrorist organizations have become a global problem that caused many countries in the international community to enact many laws and legislation to stop and reduce them.

Banks are considered one of the most important circles where illegal money laundering takes place and that is because of the complexity of these banks in banking operations, speed and overlap, which confirms the central role in the discretion of the illegal funds from illegal sources and to giving them the status of legitimacy. Banks can have a more obvious role especially with the progress of banking operations and the use of modern technological methods, since the modern electronic services can be used in a manner contrary to the law, taking into account that the majority of these operations are done automatically and their supervision needs effort, time and costs, let alone to its contradiction with banking secrecy and of course this increases the difficulty of banking supervision.[18]

\section{MONEY LAUNDERING}

Money laundry has been defined as "the use of money derived from illegal activity by concealing the identity of the individuals who obtained the money and converting it to assets that appear to have come from a legitimate source. "We can simplify things by saying that money laundering is a process to make dirty money appear to be clean.[8] As shown in Figure (1).

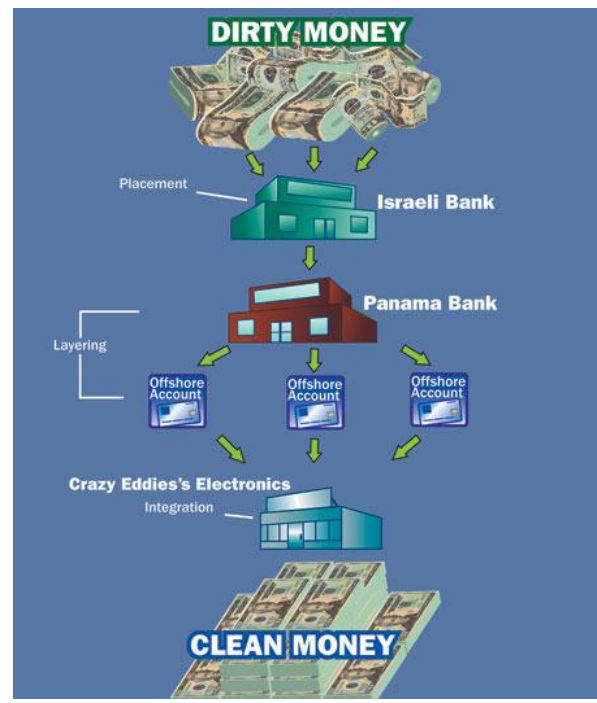

Figure (1) : money laundering

\section{HISTORICAL BACKGROUND}

The term money laundering was coined in the famous 1920 s gangster era of American history. Between gambling, prostitution, and sales of prohibition alcohol, there was a lot of cash that required laundering. In other words, a method or methods had to be developed so that the government did not become suspicious about the true nature of a gangster's funds. The major headache that gangsters faced was that the money they "earned" was in the form of cash currency and often in small-denomination bills or coins. If the funds were put into the bank, then questions would be asked by the bank and 
ultimately the government. Further, storing large amounts of money in low value coins is a physical and logistic nightmare. So, the gangsters created businesses, one of which involved slot machines and another of which was laundromats. The coins could be used to "gamble" and to "wash clothes" Of course, the number of coins actually used far exceeded the true amount gambled or used at the laundromat, and it was made to appear that more gambling or more clothes were washed than actually were. And so, it is said, the term money laundry was born.

While the term money laundering has been around since the early 20th century, the ideas and economics of money laundering have been around for thousands of years. Four thousand years ago, in China and other Asian countries, ruling parties took advantage of merchants to get more funds. In turn, the merchants became skilled at moving money around without it being identified and seized.[9]

\section{MONEY LAUNDERING CYCLE}

Money laundering is carried out in three phases, As shown in Figure (2) :

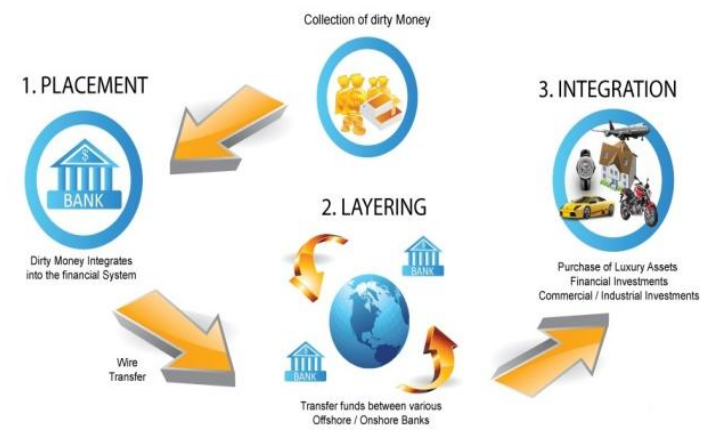

Figure (2) : Cycle Money Laundering

\subsection{Placement}

The process of placing, through deposits or other means, unlawful cash proceeds into traditional financial institutions. At this stage cash derived from criminal activity is infused into the financial system. The placement makes the funds more liquid since by depositing cash into a bank account can be transfer and manipulated easier. When criminals are in physical possession of cash that can directly link them to predicate criminal conduct, they are at their most vulnerable. Such criminals need to place the cash into the financial system, usually through the use of bank accounts, in order to commence the laundering process.

This is the first stage in the washing cycle. Money laundering is a "cash-intensive" business, generating vast amounts of cash from illegal activities (for example, street dealing of drugs where payment takes the form of cash in small denominations). The monies are placed into the financial system or retail economy or are smuggled out of the country. The aims of the launderer are to remove the cash from the location of acquisition so as to avoid detection from the authorities and to then transform it into other asset forms; for example: travellers cheques, postal orders, etc. [12]

\subsection{Layering}

Constitutes the second stage of the laundering process and involves the separation of proceeds from the illegal source through the use of complex transactions designed to obscure the audit trail and hide the proceeds. This phase of the laundering process can include the transfer of money from one bank account to another, from one bank to another, from one country to another, or any combination thereof. Criminals layer transactions to increase the difficulty of tracing the proceeds back to its illegal source. They frequently use shell corporations and offshore banks at this stage because of the difficulty in obtaining information to identify ownership interests and acquiring necessary account information from them.[6]

\subsection{Integration}

Is the third stage of money laundering. In terms of money laundering, integration marks the transition from dealing exclusively in illicit funds to a state in which dirty money and clean money begin to mix. This blending together is often accomplished with creation of legitimate entities that will be used by the money laundering operation on an ongoing basis. This is often characterized by the purchase high-value assets that are difficult to track or seize. These assets often include things like high-value automobiles, airplanes, boats, or real estate purchases.In the case of Operation Polar Cap, a bank notified the IRS of unusual activity when a jewelry broker began depositing excessive amounts of cash inconsistent with his business -- \$25 million in three months. Unbeknownst to the jeweler's bank, another individual who owned a grocery store and a check-cashing business was also acting strangely at his banking institution. This bank notified the IRS when the grocery proprietor was observed taking great care to ensure the cash he deposited in the bank was never given back to him.[16]

\section{MONEY LAUNDERING METHODS IN THE BANKING SYSTEM}

Many of the banks offer financial services and banking by modern electronic methods because of technological developments, and this helped money launderers to take advantage of these techniques and developing of methods of money laundering and the abandonment of the conventional methods as much as possible to avoid the banking supervision and the impossibility of tracing sources of Illegal money, Among these methods are the following :

\subsection{Credit Cards}

Under this method, money is disbursed from banks through the ATMs of each bank Which are spread throughout the world and are considered to be the most modern cash methods in banking activities Most banks currently issue exchange cards from any of their branches and therefore the money launderer pays The money is from any machine in any foreign country.[14]

\subsection{Internet Banking}

Anyone can use the Internet to create a virtual bank or store, or to exchange currency or establish fake companies in countries that "turn a blind eye" on the operations of money laundering. In these virtual facilities money is processed online, which is easy to transport from one place to another using the Internet, and away from the control of the Executive government agencies and the specialized legal legislations related to banking operations, which makes the internet banks, an ideal and easy-to-the-money laundering, especially that the internet banks are only Virtual figures not subject to the control of legislation and Laws relating to regular commercial banks that give central banks authority to control and restrict their bank activities, due to lack of physical existence in the traditional sense, and its presence outside the spatial and legislative jurisdiction, which gives central banks the authority of banking supervision and organizing activities and 
the right of prosecution, upon the commission of any violations of the law [5].

\subsection{Electronic Banking Services:}

After the tremendous development witnessed by the world of electronic communications, modern electronic banking services are heavily used in the implementation of money laundering operations, particularly in the two phases of placement and integration like electronic funds transfer, paying bills, where it became the most common and easiest way to carry out money laundering, making it a global phenomenon beyond the borders of one state, and calling for concerted international efforts to fight it.[4]

\subsection{Electronic-Cash or Money}

Electronic money is one of the most modern methods used in money laundering, for the impossibility of tracking it, its theft and speed of movement, and not being subject to the jurisdiction of the temporal and spatial bank Legislation of the States, for the absence of physical space specific and effective in the traditional sense, where the funds may be transferred freely, without obstacles or without resorting to the services of banks and financial intermediaries, making it outside the banking supervision authorities. In addition, electronic money shall not be subject to the standards of traditional legal money imposed on exporting countries, and this requires the existence of a compulsory legal protection suitable to the exported money value, making this money subject to the issuance and conversion without any control or specific legal standards and taking it outside the jurisdiction of central banks.[3]

\section{THE ROLE OF BANKS TO PREVENT AND DETECT MONEY LAUNDERING}

Banks' commitment to effective policies and measures to counter money-laundering is one of the ways criminal criminals are prevented from using it. The involvement or involvement of the banking sector in money laundering leads to a lack of confidence in it. For this reason, most international and local organizations have taken note of the importance of the role that the banking sector can play in preventing money laundering through its commitment to exercise caution and caution in dealing with customers and their banking operations.

\subsection{Preventive Money Laundering}

\section{A- Information on proposed transactions}

A party seeking to establish a lasting business relationship shall provide details about the proposed transactions. A special questionnaire is used to obtain information from customers about intended transactions, including about the purpose of the business relationship, as well as the nature of the transactions for which Landsbankinn is to serve as an intermediary. If a specific transaction will benefit a third party, the customer shall be required to provide information as to who the third party is. A party seeking to establish a business relationship shall be asked to state the origin of the financial assets which will pass through the bank in the proposed transaction.[15]

\section{B- Check customers}

- Identify the customer

Upon opening an account in the name of a natural person, the bank shall obtain all necessary information from the official documents to prove his identity. Full information about his full name, place of residence, telephone numbers, and place of business shall be obtained from his source of income. The bank shall verify the presence of this person legally and verbally by means of the necessary documents such as certificates issued by chambers of commerce or industry or those issued by the Ministry of Industry

\section{- The final beneficiary}

The Bank must identify the final beneficiary of the transaction, whether individuals or companies. In terms of their nationalities, the nature of their activity, and the country whose banks will be dealt with to determine whether they are among the non-cooperative countries in the fight against money laundering or are known for the drug trade[11]

\section{C-Training and qualification of employees}

Banks should develop programs and plans to continuously train staff to combat money laundering, including the methods used in money laundering, how to detect and report them, and the mechanism for dealing with suspects. The instructions also recommended keeping records of all training programs carried out during A period of not less than five years, including trainees' names, qualifications and trained personnel.

The employee may inadvertently participate in the completion of certain suspicious transactions by automatically executing the transactions without realizing the great risks that may arise as a result of not being aware of the various transactions that are going on. Therefore, these transactions must be justified and supported by documents and evidence of their legality.[13].

D- Establishment of a special anti-money laundering unit The need for banks to establish an independent administration and to provide them with sufficient staff to be responsible for preventing money laundering. Recommendation 26 of the 40 Recommendations of the International Labor Committee recommended that States establish a financial information unit with the task of receiving, analyzing and disseminating information on cases of money laundering. Shall have the right to have direct and indirect access to financial, administrative, legal and timely information for their work, and shall also be granted The Committee stressed the need for States to provide the Unit with the necessary financial, human and technical resources, with the need for the State to review the efficiency and efficiency of the Unit's performance and the integrity of its staff.[13]

\subsection{Money Laundering Detection}

Can review some actions aimed at controlling the movement of funds to detect Suspicious operations of money launderers. The most important of these measures are[14]:
A- Control over extraordinary financial transactions.
B- Control of cash Transactions.
C- Control of transfers.
D- Control of trust funds
E- Trade finance operations
F- Control of letters of credit for transfer of funds between States.
G- Control of credit operations
H- Control of current accounts 
I- Control of international banking and financial transaction

\section{MONEY LAUNDERING INDICATORS}

The bank should attention to the following indicators[2] :

- The exchange of large amounts of banknotes from small categories with papers of large categories without obvious reasons.

- The deposit of large sums or repeated creations of amounts that constitute a huge volume for the client's apparent activities.

- Focus on withdrawals and cash creations instead of using bank transfers or other negotiable instruments without obvious reasons.

- Operating an account mainly to transfer large amounts to foreign countries or to receive remittances from them, while the client's activity does not appear to justify such transactions.

- Large or repetitive processes related to an external activity that appear to be disproportionate to the volume of the client's activity.

- Keeping multiple accounts for the same person and depositing cash in all these accounts so that they constitute a large sum and in proportion to the size of the client's activity.

- Deposits of checks to which the beneficiary is a third party in large amounts and in favor of the account holder but does not appear to be consistent with the accountant's relationship or the nature of his work.

- Directly transfer deposits in the account directly or in similar amounts, which are in large amounts.

- The account receives multiple small conversions electronically and then makes large conversions the same way to another country.

- The large volume of wire transfers to and from banks in countries known as money laundering centers.

- The large size of the traveler's checks and the serial number of mailings addressed to the same beneficiary.

- Multiple requests for issuance of traveler's checks or bank checks in foreign currencies in amounts not commensurate with the nature of customer activity.

- Opening documentary credits in large amounts that are not commensurate with the nature and size of customer activity, or that the beneficiary is one of the clients closely related to the customer abroad.

- Debit of commercial papers for which the beneficiary is a non-resident foreign party or unknown to the Bank.

\section{THE NEGATIVE EFFECTS OF MONEY \\ LAUNDERING}

Money laundering has negative effects on the national economy, As they undermine development efforts and lead to economic imbalance, and a threat to safety Financial institutions, and inequitable distribution of resources within society. We will try to identify below On the most important economic, social and political effects of money laundering[1][7][10] .

1) The transfer of funds and their employment in other countries for the purpose of laundering them deprives the State of origin of exploitation This money in the development of its economy and the elimination of unemployment in them.

2) Money laundering by buying luxury goods leads to increased consumption and shortage Saving, and then to the economic imbalance is to increase inflation and increase imports and deficit

3) the escape of money from tax evasion as being the result of unlawful activities, Leads to a shortage of state resources which may result in new taxes or increases Public debt by borrowing to meet the deficit.

4) The flight of money to the laundering abroad leads to a shortage of national savings and therefore Failure to meet the investment requirements, which may lead to borrowing from abroad to fill the deficit, Thus, the state falls under the burden of external indebtedness.

5) Money laundering may lead to the closure of banks that are convicted in the country that penalizes institutions In case of involvement in money laundering operations such as the United States of America, and good An example is the Credit and International Trade Bank, which has been proven involved in laundering Money in Pakistan and Latin America.

6) Increased money laundering leads to increased spending on security by increasing the number of its members And equipped with modern means, and this may be at the expense of development projects.

7) to replace the national currency derived from the illegal activities with foreign countries with the aim of Transfer and laundering resulting in the devaluation of the national currency.

8) The illegal owners withdraw their deposits from the national banks suddenly for the purpose of laundering them, leading to confusion of these banks and confusion in the national currency market.

9) Money-laundering is negatively impacted by channeling funds into areas of commercial activity Finance and consumption rather than industrial and agricultural production To negatively affect the national outcome, because these funds return from washing usually seeks to Rapid profit and not to the added value added to the investment.

10) Fugitive funds abroad in international banks to conduct washing operations lead to Increasing the tax burden and decreasing savings and investment rates and thus weakness Productivity

11) Wealth that is achieved for some owners of illegal entry leads to imbalance in values As well as the dominance of physical values The social values of the work of a product, the deepening of individual and selfish utility values, and poor distribution Income by converting income from the productive poor to unproductive artistic classes, And the social imbalance in society.

12) Money-laundering supports and protects crime and helps to increase its rates locally There is also a significant correlation between money laundering and corruption In all its forms. It corrupts the administrative apparatus by bribing lawenforcement officers and men of arrest Criminal and customs authorities to turn a blind eye to their illegal activities, and to corrupt men The judicial system is bribed and, failing that, may resort to liquidation.

13) Money-laundering in a State damages the reputation and credibility of the State International forums, which is detrimental to the national economy of the state as a result of the escape of investment (Foreign investment is necessary for the development process). 
14) Money laundering affects the status of the State and its reputation before international bodies Donors for aid and loans are especially needed for developing countries that are in dire need of these (Assistance to complete development programs) .

15) The accumulation of wealth in money earners leads to a feeling of power and influence that drives them to (Intervention to influence the political decision in order to serve their interests)

16) Money laundering corrupts the political system, sometimes money launderers resort to Campaigning for some politicians even if they succeed in elections Supporting them, and this would affect the process of political stability and security.

\section{CONCLUSION}

In order to improve the current situation, we suggest some recommendations: Undoubtedly, training bank employees (as one of the executive organizations), have an effective role in the development of anti-money laundering and financing of terrorism literature and more efficient and faster implementation of the directive. Hence, it is required to establish training sessions for the staff and register these training courses. However, "All subject individuals are responsible for establishing on-the job training sessions in the field of money laundering programs for the employees. These sessions should be in order to introduce the rules, regulations and guidelines on the performance of money launderers and especially their latest techniques. Participating mentioned sessions is necessary for employees to continue their jobs and the records of those sessions must be recorded." Preparation of software infrastructure for the banking system is of great importance. Enforcement of many existing regulations possible using anti-money laundering software. The teller, alone, cannot check all regulations on cash deposits and withdrawals, the level of customer activity and so on, thus the help of powerful software is needed. authorities and should not insist upon attracting resources at any cost and must perform it under anti-money laundering regulations. This concern of banking authorities while the current banking system is in need of funds and along with paying mandatory facilities by the law seems reasonable. However, it is important to note that, the absence of financial resources resulting from criminal activities will not damage banking processes. More than anything else, money launderers want to clear their money and as soon as the problem was solved they will commit another crime for new financial interests. Therefore, if the banker is looking to attract such resources, due to the non-persistence of this resource, he must answer two questions. First, why you failed to maintain the client and second, why did you allow the money derived from criminal activities into the bank. As noted, prevailing public atmosphere has created patterns of behavior that need serious changes. To implement these changes, various measures can be considered. Some of these measures must be taken beyond the banking system. For example, the national media should identify the problem and attempt to analyze the cultural situation in developed countries, and at the same, try to localize the solution and inform people. Finally, It is necessary to note that, the purpose of above issues is not neglecting needs of people and the lack of flexibility of banks in order to facilitate their services but they are mentioned to provide real and honest information of the clients of banking system.

\section{REFERENCES}

[1] Abdullah Al-Saidi, 2000, "A Study on Hidden Economy Crimes: Tax and Customs Evasion and Money Laundering." Conditional Thought, Volume 9, Issue 1.p21

[2] Al-Ahmadi, Essam Al-Din (2000) "Money laundering phenomenon and its economic effects and the most important global and local efforts to combat it." Journal of the Union of Arab Banks, No. 236 Volume 20.

[3] Al Faouri, A. F., \& Qteishat, E. M. (2002). The Crime of Public Money Laundering and Leal Nature (1st ed.). Dar Wael for Publication, p92.

[4] AL Kusoos, R.N. (2002). Money Laundering Crime of the Century (Comparative Study) (1st ed.), Dar Wael for Publishing and Distribution, Amman, p41.

[5] Barakat, I. M. (2007). The Importance of Disclosure of the Risks of Financial Transactions Relating to Money Laundering in Commercial Banks: An Analytical Study in the Light of the Theory of Social Responsibility. Research presented to the Scientific Conference of the seventh annual risk management and the knowledge economy Axis VII risk management and accounting, university of Zaytuna, Jordan, Amman, p 16-18.

[6] Dionysios S. Demetis, 2010, "Technology and AntiMoney Laundering A Systems Theory and Risk-Based Approach", Edward Elgar Publishing Limited, 15 Lansdown Road, p12.

[7] Hilal, Mohamed Naji, 2003, "The Social Dimension of Money Laundering Crime: A Study of Laundering, Money Resulting from Corruption in the Developing World," Police Thought, Volume 12, Issue 4.p55-65.

[8] John madinger,2012, " money laundering a guide for criminal investigators", Taylor \& Francis Group, p5.

[9] Kevin Sullivan, " Anti-Money Laundering in a Nutshell", Apress, p10.

[10] Mohsen Abdelhamid, 1999, "Economic and Social Impacts of Organized Crime and Attempts to Confront Regionally and Internationally". Naif Arab Academy for Security Sciences, Riyad.

[11] Musallah Tarawneh, Hossam Al-Batosh, 2005, "The Basis of Banks' Commitment to Combating Money Laundering Operations and the Scope of this Commitment in the Jordanian Legal System", Journal of Law, Issue 3, p48.

[12] Naeem Salama, 2012, " Banks and money laundering", Journal of Baghdad College of Economic Sciences,p355.

[13] Rana Farooq Abandoned. 2008, "The Role of Banks in Controlling Money Laundering Operations A Practical Study on Palestinian Banks in the Gaza Strip" Master Thesis, Accounting Department, Faculty of Commerce, Islamic University, Gaza, pp. 13, 14, 46,

[14] Saqr Moutiri, 2004, "The Money Laundering Crime (A Study on its Concept and the Limitations of its Investigation and the Problems of Coordination of International Efforts to Confront it", (Master Thesis), Naif Arab University for Security Sciences, 
[15] Sonja Cindori, 2007, " The Money Laundering Prevention System", Financial Theory and Practice 31 (1), 59-76.

[16] Tayel Kayed Majali, 2012, "Money Laundering and its Impact on the Spread of Drugs", Hashemite Kingdom of Jordan, Public Security Directorate, Naif Arab University for Security Sciences, p9

[17] Tayeb Majid Hamed, 2014, " Anti-money laundering mechanisms in the machine Banker in Iraq", Journal of
Baghdad College of Economics, Number Thirty - ninth, p187.

[18] Naim Salameh Al-Qadi, Aiman Abu Al Haj, M. Mousa Matar, Mashhour Hathloul, 2012," The Positive and Negative Role for Banks in Money Laundering Operations", Canadian Social Science Vol. 8, No. 5, 2012, pp. $13-23$ 